\title{
Financial Status, Parents Influence, Peer Influence and Self-Choice of Students in Selection of Strand in The Senior High School, Cebu, Philippines
}

\author{
Aldrich Luigi C. Tortor \\ Student, Jagobioa National High School \\ North Road, Jagobiao, Mandaue City, Philippines \\ E-mail: luigitortor145@gmail.com \\ Rosalie L. Ohayas \\ Master Teacher, Cebu, City, Philippines \\ E-mail: Rosalie.ohayas@ deped.gov.ph \\ Jerald C. Moneva \\ Pratical Research Professor, Jagobioa National High School \\ North Road, Jagobiao, Mandaue City, Philippines \\ E-mail: monevajerald5@gmail.com
}

Received: January 15, 2019 Accepted: March 2, 2020 Published: March 25, 2020

doi:10.5296/ber.v10i1.16241ＵRL: https://doi.org/10.5296/ber.v10i1.16241

\begin{abstract}
Selecting a strand is a crucial act to every student in such way that they have to considered their financial status, parents and peer suggestion, and also their self-choice in acting on it. This study investigates whether financial status with self-choice; parents influence with self-choice; and peer influence with self-choice are having an association with each other in selecting a strand. 214 of students by complete enumeration answered the questionnaire on financial status and likert-scale for parental influence, peer influence, and self-choice and the data gathered been analyzed via weighted mean, frequency, chi-square and lambda in determining their association. The result shows that the financial status of students in school
\end{abstract}


alone is inclined to self-choice in the selection of a strand but not with parental and peers influence in selecting a strand. In other words, parents and peers show no significant association with self-choice of students, though the influences of parents and peers are noticeable.

Keywords: Financial status, Parents influence, Peer influence, Self-choice, Selecting a strand

\section{Introduction}

\subsection{Rationale}

Selecting a strand to be taken in senior high is a crucial decision for students', because their futures inclined with it. With the help of their parents and peers also considering their financial status and chosen careers, students come up a firm decision on what strand should they take. The researcher believed that by considering this aspect, it become an assurance that they choice a right strand for their future. Parents play significant role for their child in selecting a strand because of two reasons: one is because they are the one who provide the financial for tuition fee and other expenses for their child, second is because they can dictate or influence their child on what strand should they take on. Same goes for the peers, which they can influence the students' strand decision making, aside that they can't dictate or provide the financial expense of students. When students consider their financial status, they also considered their financial capability that they have, and by this, they choose a strand that suit on the range of their financial capability. Financial status has three class: low class, middle class and elite class. Since the financial status of most in public school are low and middle class, financial status is further categorized into low-lower class, low-upper class, middle-lower class and middle-upper class. When students consider their self-choice, most of them choose a strand that they dream of or a strand where they exile most or the insured one (strand) where they future is secured.

Meanwhile, Jagobiao National High School-Senior High School (JNHS-SHS) has currently five strands to offer for the students to be more familiar to their strand specialization. These strand specializations include Accountancy and Business Management (ABM), General Academic Strand (GAS), Humanities and Social Sciences (HUMSS), Technical-Vocational Livelihood/Drafting (TVL) and Science, Technology, Engineering and Mathematics (STEM). The researcher observes that numbers of students' in school choose HUMSS, GAS and STEM most than ABM and TVL in selecting strand in senior high. Which quite surprising because ABM, TVL and STEM is much higher of demand in economy than HUMSS and GAS. Then, maybe most of the students' must be choose their strand on what they like most.

Career choice of students is significant on the profile of students' in selecting a strand (sex, family income, occupation of the head of the family, school preference and average scholastic rating) in selecting a strand (Abarro, 2016). There are three factors that can affect students' strand selection and these are the environment factors, personality factors, and family factors (Kaneez \& Medha, 2018). There are also other factors that can affect students' career decision such as school, personal and family factors (Su et al., 2016). However, policies alleviating income, which increases permanent income well, become a result to alter schooling decision 
of students' (Chevalier et al., 2013).

On the factors identified by the researcher in selecting a strand on senior high. Choosing a strand, there has to be an alignment between these factors and financial status of students in order to attain a successful career. In short, if there is an association between these financial status with factors affecting students strands selections, then the student can guarantee a successful career. Based on the observation between financial status with factors in affecting strand selections, this study seeks to answer about how students select a strand and how it correlates with their financial status.

\subsection{Theoretical Background}

This chapter represents the theory that will support this study. John Holland's developed the Holland's theory in 1996. Holland's theory of career choice focused on searching a career for a prefer jobs. In addition, Holland's theory has six personality types: Realistic, Investigative, Artistic, Social, Enterprising, and Conventional (RIASEC). Realistic refers to someone who likes working alone or with other realistic people. Investigative refers to someone who is a "thinker" who strives to complete tasks and often prefers to do so independently. Artistic refer to someone are imaginative and usually extroverted. Social refers to someone who tends to be concerned with social problems and wants to help others. Enterprising refers to someone who are enterprising lean toward leadership roles. Who are willing to take on challenges and are often extroverted persons. Conventional refer to someone who is prefers structured tasks and tending to details. He or she is often conservative. Mostly people have one of the personality types and usually use as a basis of choosing career or strands. Also, choosing career base RIASEC it will increase the satisfaction and academic success of students. Holland emphasizes that people who choose to work or study in an environment that similar to their personality are more likely to be successful and satisfied (Holland, 1996).

Applying the Holland's theory in selecting a career of students, it be could relate to the factors in selecting the strands base on their financial status. The six personality's types of Holland's theory might have the correlations with the financial status of students. For example, the realistic personality type of students, these are the students who choose their strands according to their status or the practical way of choosing strand. The investigative personality type of students, these are the students who choose their strand according to their ideal career or dream career, even if their financial status is low because they might and can find a way to sustain the chosen strand. The social personality types of students, these are the students who choose their strand without giving more consideration with their financial status. Furthermore, their financial status is on average or above average so they tend to be more concern with the social problem and help others than their financial status. The enterprising personality type of students, these are the students who choose their strand in order to challenge their self and maybe to know to what extent of their financial capability is. The conventional personality type of students, these are the students who choose their strand based on their financial status accordingly, because they think more logically and practically to what strand or career, they capable of in terms of money to afford the need and necessity of their chosen strand (Holland, 1996). 


\section{Macrothink Institute $^{\mathrm{TM}}$}

Selecting a strand is mostly base to the six personalities type RIASEC. In addition, the theory shows that all individuals have a basis in selecting a strand. By basing their selected strand to six personality's type, it can increase the satisfaction and academic success as a student.

\subsection{Statement of Problems}

This study intends to assess the financial status and what factors greatly affect students strand selection in senior high.

Specially, this study seeks to answer the following problems:

1.) What is the profile of students in Jagobiao National High School-Senior High School in terms of?

\subsection{Financial Status}

1.2 Parents Influence

\subsection{Peer Influence}

\subsection{Self-Choice}

2.) Is there a correlation between self-choice of student with the financial status; self-choice of students with parents' influence; and self-choice of students with peer influence that greatly affect students strand selection?

Null Hypothesis

H0 - There is no significant association between self-choice with the financial status; self-choice of students with parents' influence; and self-choice of students with peer influence in affecting their strand selection in Senior High School.

H1 - There is significant association between self-choice and the financial status; self-choice of students with parents' influence; and self-choice of students with peer influence in affecting their strand selection in Senior High School.

\subsection{Significant of the Study}

The study was conducted on purpose that can give benefits especially the people who are the target of the study. The study can give awareness, information, and knowledge to beneficiaries about financial status and strand preference of students in Senior High School. The beneficiaries for this study would be:

The students who are the main target of study. It will give an idea about their financial status and what factor greatly affect their decision making in selecting a strand.

The teachers will be aware about the financial background of their students. They will obtain recommendation to assess the students' factor in selecting their strand.

The parents will obtain an idea about how to manage their financial capability according to what strand their child has chosen in order to support their child financially. 
The study will inform the school head about the financial status and factors in affecting strand selection of student. Also, they have authority that can generate a program to assess the financial status in order to create a resolution.

This study will improve and strengthen the relationship with the community, knowing what financial status student belong and what factors greatly affect their decision making.

Lastly, in this research, the researcher \& future researcher can achieve importance and knowledge of what factor greatly affect student decision making in selecting a strand. Researcher could enhance study engagement strategy, skills and understanding.

\section{Review of Related Literature}

Selecting a strand is a crucial phase to every student because of the factors that needed to be considering before they arrive to a certain career. Lots of authors have revealed many factors that can affect students' decision making in selecting strand. Some of this factors are environment, personality and opportunity factors (Kaneez \& Medha, 2018); psychological (interest, prestige, personality and self-esteem), sociological (peer group, mentors, governmental policies and socio-economic status of parents), economic (poverty, needs, demands and wants), hereditary (physical appearance and aptitude) and educational factors (position of students in school and acquired skills) (Obiunu \& Ebunu, 2010); sex, average family monthly income, school preference, occupation of the head of the family and average scholastic rating in the preceding years (Abarro, 2016); media, financial constraints and academic performance (Kazi \& Akhlaq, 2017); personal factors, family factors, school factors and career exploration factors ( $\mathrm{Su}$ et al., 2016); outcome expectancies, gender, personal interests, learning experiences, environmental factors and personal contacts (Edwards \& Quinter, 2011). To every student this is the crucial phase is choosing a career. Moreover, student already face such financial problems like expenses that exceed on their income receive, use savings to coop the financial constraint, how to earn money and manage it to long last and make loan to support the cost of living (Daud et al., 2018). The reason behind this problem is the inability to manage well their financial resources but despite of this circumstances they still able to focus on their studies (Jariah et al., 2004). In addition, upon completing their selected course students' will experience the high level of satisfaction on their (Freeman et al., 2016).

Lower family support well result to greater financial stress and anxiety in selecting a strand (Tran et al., 2018). Additionally, family socio-economic status also has significant relation to academic performance of students (Sollano et al., 2018). Because family size, parents' backgrounds, parent's qualifications and parents' level of income is significant in affecting the academic performance and selection of strands (Abdu-Raheem, 2015). However, students who have different level socio-economic status are also having a different level on academic achievement (Bhat et al., 2016).

Permanent income is significant for student in attending post-compulsory education even some of them are experiencing financial constraint that affect their decision making to attend (Chevalier et al., 2013). To solve this financial constraint of many students' they seek help 
from financial counselor or advisor, financial aid counselor, credit counselor in order to finance their tuition and they called financial help-seekers (Lim et al., 2014). However, environment, nor personality, nor opportunity factors have significance in determining the career choice of students in either private or public school (Eremie \& Okwulehie, 2018).

Peer group and students' environment are strong predictors in affecting students' decision making in selecting their strand that they aspire for (Obiyo \& Eze, 2015). Because family influence is essential factor on choosing their career (Fouad et al., 2016). Additionally, stable family socio-economic status well provides comfort, positive attitude, and healthy environment for the students that will lead them in attaining the high academic achievements (Saifi \& Mehmood, 2011). Income, occupation and level of educations of parents are directly associated to academic performance of students (Kumar, 2016).

Moreover, career success of students' can be best attained if the strand selected is suited to the innate ability and intellect, and personality of students with the proper guidance of school in choosing the right career in senior high and college (Pascual, 2014). In addition, students seek to work at such prestigious occupation while still in secondary school because of the opportunity and it does affect the strand selection of the students' but because of lack of financial support it became impossible for them, due to lack of training required for the occupation (Olamide \& Olawaiye, 2013). Life satisfaction of students was highly associated with anxiety which they experience while selecting a strand and it because of financial stress (Bernardo \& Resurreccion, 2018).

Parents support has much to do in influencing the strand selection of students (Aguado et al., 2015). Parents have played a vital role in influencing their child what strand to be choose in SHS (Hellen \& Kitainge, 2016). Additionally, parents' income does affect academic achievement of students' in selecting a strand (Dahie et al., 2016). Because they look up their parents in choosing their future career (Braza \& Guillo, 2015). In comparison, socio-economic and educational background of parents shows that these are not significant factors to affect the academic achievement of the students in their selected strand (Ogunshola \& Adewale, 2012).

However, selecting a strand was inclined with the security and motivation, which highly ranked factors such as exploration, advancement, opportunities, exposure and knowledge which are responsible in selecting a career. This concludes that having background knowledge about the career is essential in building an interest towards the career (Nyamwange, 2016). In addition, family income is a significant predictor that boosts the dimensions of self-esteem (lovability, likability and self-control) of students towards the strand they choose (Mandara \& Murray, 2000).

\section{Research Methodology}

This chapter presents the design; environment, respondents, instruments, data gathering procedure and statistical treatment that made to complete the study. 


\subsection{Design}

The researcher uses a descriptive correlation research design. The researcher aims to know the correlation between financial status and self-choice; parents influence and self-choice; and peer influence and self-choice in affecting students strand selection in SHS.

\subsection{Environment}

The study is conduct in Jagobiao National High School- Senior High School (JNHS-SHS). The JNHS-SHS compose of 8 classrooms and 5 strands that indicate ABM, HUMSS, GAS, STEM, and TVL.

\subsection{Respondent}

The study focuses on senior high school students in JNHS-SHS. A total of 214 students is chosen as respondents because they are more suitable to answer the questions about financial status and factors in affecting students strand selection in senior high school and in a random sampling.

\subsection{Instrument}

The researcher uses a multiple-choice questionnaire in knowing the financial status of Jagobiao National High School students and Likert scale questionnaire in knowing which factors is greatly affect students strand selection in senior high, which were based on a statement of problem and researcher perception.

\subsection{Data Gathering Procedure}

Before the researcher undergo in data gathering, the researcher asks the school principal for permission to conduct a study in Jagobiao National High School, by submitting a transmittal letter, then, the researcher immediately proceed to gather the data by distributing the formulated questionnaire which are multiple-choice and Likert scale to the senior high student personally, in order to accommodate an appropriate response, after they done answering the researcher collect the given questionnaire and input the data been gathered on excel.

\subsection{Statistical Treatment}

The weighted mean, frequency, chi-square, and lambda are uses in this research study. A weighted mean is use to identify the mean of each questionnaire and frequency to identify the number of students in each category. The chi-square is use to determine significant between the financial status and self-choice. Lambda is use to determine the relationship and association between parents influence with self-choice; and peer influence with the self-choice of student in selecting their strand in senior high.

\section{Analysis and Interpretation of Data}

This chapter presents and display the data been gathered, it also shows the analysis and interpretation of data. The purpose of this study was to identify if there is a significance relationship between the financial statuses of students to their strand that they choose. 
Table 1. Financial Status

\begin{tabular}{|l|l|l|}
\hline Indicators & Frequency & Percentage \\
\hline Low Lower Class & 52 & $24.30 \%$ \\
Low Upper Class & 119 & $55.61 \%$ \\
Middle Lower Class & 31 & $14.49 \%$ \\
Middle Upper Class & 12 & $5.61 \%$ \\
\hline Total & 214 & $100 \%$ \\
\hline
\end{tabular}

$\mathrm{N}=214$ Legend: $1.000-12,500=($ Low Lower Class $) ; 12,501-25,000=($ Low Upper Class $)$; 25,001-37,500 $=($ Middle Lower Class); 37,501-50,000 $=($ Middle Upper Class $)$

The table above show the number of students' who have different class of financial status such as low lower class (0-12,500), low upper class (12,501-25,000), middle lower class $(25,001-37,000)$ and middle upper class $(37,001-50,000)$. The number of respondents who have low upper class of financial status is 127 or $55.61 \%$. Followed by the number of respondents who have low-lower class of financial status is 59 or $24.30 \%$. Then the number of respondents who have middle lower class of financial status is 45 or $14.49 \%$. Lastly, the number of respondents who have middle upper class of financial status is 12 or $5.61 \%$. This revealed the number of students' of JNHS-SHS in each class of financial status but majority of the students are inclined to Low Upper Class of Financial Status.

Family financial income has positively correlation to the academic achievement of students in their chosen strand (Dahie et al., 2016). On the contrary, there is no significant relation between academic performance of students on their chosen strand, socio-economic and educational background of their parents (Ogunshola \& Adewale, 2012). Additionally, parental socio-economic status is not strongly significant to students in selection of strand (Obiyo \& Eze, 2015).

Table 2. Parental Influence

\begin{tabular}{|l|l|l|}
\hline Indicators & Weighted Mean & Interpretation \\
\hline 1.I seek my parents' advice in choosing strand. & 2.65 & Agree \\
\hline 2. I choose this strand based on my parents' occupation. & 2.11 & Disagree \\
\hline 3. My parents recommend me to take this strand. & 2.40 & Disagree \\
\hline $\begin{array}{l}\text { 4. I choose this strand based on my } \\
\text { parents' perception of my future career. }\end{array}$ & 2.46 & Disagree \\
\hline $\begin{array}{l}\text { 5. I choose this strand based on my } \\
\text { parents' moral support. }\end{array}$ & 2.55 & Agree \\
\hline Overall Weighted Mean & 2.43 & Disagree \\
\hline
\end{tabular}

$\mathrm{N}=214$ Legend: $1-1.75$ = Strongly Disagree, 1.76-2.5 = Disagree, $2.51-3.25=$ Agree, 3.26-4 = Strongly Agree

The table above shows the weighted mean of each statement and overall weighted mean, which is 2.43 (disagree). Mean to say, parents' factors have weak relation in selecting a strand of students in JNHS. The highest weighted mean above all is statement 1 , which is 2.65 
(agree), followed by statement 5 , which is 2.55 (agree), and lastly statement 4 , which is 2.46 (disagree).

Table 3. Parental Influence

\begin{tabular}{|l|l|l|}
\hline Indicators & Frequency & Percentage \\
\hline Not Influential & 7 & $3.27 \%$ \\
\hline Slightly Influential & 58 & $27.10 \%$ \\
\hline Moderately Influential & 114 & $53.27 \%$ \\
\hline Completely Influential & 35 & $16.36 \%$ \\
\hline Total & 214 & $100 \%$ \\
\hline
\end{tabular}

$\mathrm{N}=214$

The table above shows the number of students who have considered their parents in selecting a strand. The numbers of respondents who have consider their parents influence not influential in selecting a strand is 7 or $3.27 \%$. Followed by the number of the respondent who have consider their parents influence slightly influential in selecting a strand is 58 or $27.10 \%$. Then the number of the respondent who have consider their parents influence moderately influential in selecting a strand is 114 or $53.27 \%$. Lastly, the number of the respondent who had considered their parents influence completely influential in selecting a strand is 35 or $16.36 \%$. This reveal the number of respondents in each category but the majority of the respondent are inclined to moderately influential in considering their parents in selecting a strand in SHS.

Family financial status is significant to boost the dimension of self-esteem such likability, lovability, and self-control (Mandara \& Murray, 2000). Family income is significant to career choice of students (Abarro, 2016). However, family current income is also significant when it comes to decision making in choosing what kind of strand will the students chose because some of students' family current income is not enough to afford the strand that they experiencing financial constraint (Chevalier et al., 2013).

Table 4. Peer Influence

\begin{tabular}{|l|l|l|}
\hline Indicators & Weighted Mean & Interpretation \\
\hline 1. I consult my friends before choosing a strand. & 2.47 & Disagree \\
\hline $\begin{array}{l}\text { 2. I go by the trend in class/campus in } \\
\text { choosing the strand. }\end{array}$ & 2.22 & Disagree \\
\hline 3. My peer group recommends me to take this strand. & 2.38 & Disagree \\
\hline $\begin{array}{l}\text { 4. I and my peer group share thoughts and } \\
\text { opinion in choosing strand. }\end{array}$ & 2.72 & Agree \\
\hline $\begin{array}{l}\text { 5. My friends will acknowledge me if I choose } \\
\text { the strand same with them. }\end{array}$ & 2.44 & Disagree \\
\hline Overall Weighted Mean & 2.45 & Disagree \\
\hline
\end{tabular}

$\mathrm{N}=214$ Legend: 1-1.75 = Strongly Disagree, 1.76-2.5 = Disagree, 2.51-3.25 = Agree, 3.26-4 = Strongly Agree 
The table above shows the weighted mean of each statement and overall weighted mean, which are 2.45 (disagree). Mean to say, peer factors have weak relation in selecting a strand of students in JNHS. The highest weighted mean above all is statement 4, which is 2.72 (agree), followed by statement 1 , which is 2.47 (disagree), and lastly statement 5 , which is 2.44 (disagree).

Table 5. Peer Influence

$\mathrm{N}=214$

\begin{tabular}{|l|l|l|}
\hline Indicators & Frequency & Percentage \\
\hline Not Influential & 7 & $3.27 \%$ \\
\hline Slightly Influential & 55 & $25.70 \%$ \\
\hline Moderately Influential & 128 & $59.81 \%$ \\
\hline Completely Influential & 24 & $11.21 \%$ \\
\hline Total & 214 & $100 \%$ \\
\hline
\end{tabular}

The table above shows the number of students who have considered their peer in selecting a strand. The numbers of respondents who have consider their peer influence not influential in selecting a strand is 7 or $3.27 \%$. Followed by the number respondent who has considered their peer influence slightly influential in selecting a strand is 55 or $25.70 \%$. Then the number of the respondent who has considered their peer influence moderately influential in selecting a strand is 128 or $59.81 \%$. Lastly, the number of the respondent who has considered their peer influence completely influential in selecting a strand is 24 or $11.21 \%$. This reveal the number of respondents in each category but the majority of the respondent are inclined to moderately influential in considering their peer in selecting a strand in SHS.

Sociological factors which peer groups are include is also affect the career decision of students' in selecting their strand (Obiunu \& Ebunu, 2010). Additionally, peer groups and students' environments are essential factor in affecting students strand selection in Senior High (Obiyo \& Eze, 2015). However, peer group is least considered in strand selection of students in senior high (Pascual, 2014).

Table 6. Self-choice

\begin{tabular}{|l|l|l|}
\hline Indicators & Weighted Mean & Interpretation \\
\hline $\begin{array}{l}\text { 1. I based my chosen strand on the basis of } \\
\text { my skills and abilities. }\end{array}$ & 3.12 & Agree \\
\hline 2. I choose this strand based on my dream career. & 3.19 & Agree \\
\hline $\begin{array}{l}\text { 3. I choose this strand based on the satisfaction } \\
\text { that I will get soon from my future job. }\end{array}$ & 3.21 & Agree \\
\hline 4. I choose this strand based on my interest. & 3.13 & Agree \\
\hline 5. I choose this strand because I'm good at doing at it. & 2.96 & Agree \\
\hline Overall Weighted Mean & 3.12 & Agree \\
\hline
\end{tabular}

$\mathrm{N}=214$ Legend: 1-1.75 = Strongly Disagree, 1.76-2.5 = Disagree, 2.51-3.25 = Agree, 3.26-4 = Strongly Agree 
The table above shows the weighted mean of each statement and overall weighted mean, which are 3.12 (agree). Mean to say, self-choice factors have strong relation in selecting a strand of students in JNHS. The highest weighted mean above all are statement 3, which is 3.21 (agree), followed by statement 2, which is 3.19 (agree), and lastly by statement 4 , which is 3.13 (agree).

Table 7. Self-choice

$\mathrm{N}=214$

\begin{tabular}{|l|l|l|}
\hline Indicators & Frequency & Percentage \\
\hline Not Influential & 2 & $0.93 \%$ \\
\hline Slightly Influential & 11 & $5.14 \%$ \\
\hline Moderately Influential & 83 & $38.79 \%$ \\
\hline Completely Influential & 118 & $55.14 \%$ \\
\hline Total & 214 & $100 \%$ \\
\hline
\end{tabular}

The table above shows the number of students who have considered their self-choice in selecting a strand. The numbers of respondents who have consider their self-choice not influential in selecting a strand is 2 or $0.93 \%$. Followed by the number of respondents of who have to consider their self-choice slightly influential in selecting a strand is 11 or $5.14 \%$. Then, the number of respondents who have considered their self-choice moderately influential in selecting a strand is 83 or $38.79 \%$. Lastly, the numbers of respondents who have consider their self-choice completely influential in selecting a strand is 118 or $55.14 \%$. This reveal the number of respondents in each category but the majority of the respondent are inclined to completely personal in considering their self-choice in selecting a strand in SHS.

Peer groups and students' environments are strong predictors in affecting students to choose what vocational (Obiyo \& Eze, 2015). However, career selection of students is significant with their profile (sex, family income, occupation of the head of the family, school preference and average scholastic rating) (Abarro, 2016). Because having background knowledge about the career is essential in building self-interest (Nyamwange, 2016).

Table 8. Self-choice and Financial Status in selecting a strand

\begin{tabular}{|l|l|l|l|}
\hline & Value & Df & Asymp. Sig. (2-sided) \\
\hline Pearson Chi-Square & $59.956^{\mathrm{a}}$ & 42 & .036 \\
\hline Likelihood Ratio & 64.600 & 42 & .014 \\
\hline Linear-by-Linear Association & .041 & 1 & .840 \\
\hline N of Valid Cases & 214 & & \\
\hline
\end{tabular}

a. 41 cells $(68.3 \%)$ have expected count less than 5 . The minimum expected count is 17 .

The table above shows that there is a significant association between self-choice with financial status in selection of strand in Jagobiao National High School-Senior High School. Therefore, self-choice with financial status in choosing strand is correlated with each other because the p-value (0.036) is lesser than the significance level (0.05). 
Parents' income has a significant relationship between the performance of with their chosen strand in Senior High (Dahie et al., 2016). However, parental income and financial background of family are not strongly significant to student's career choice (Obiyo \& Eze, 2015). In addition, socio-economic status of parents does not significant to correlate with the performance of students in selecting their strand (Ogunshola \& Adewale, 2012).

Table 9. Self-choice and Parents Influence in selecting strand

\begin{tabular}{|l|l|l|l|l|l|}
\hline $\begin{array}{l}\text { Nominal by } \\
\text { Nominal }\end{array}$ & & Value & $\begin{array}{l}\text { Asymp. Std. } \\
\text { Error }^{\mathrm{a}}\end{array}$ & Approx. T & Approx. Sig. \\
\hline \multirow{3}{*}{ Lambda } & Symmetric & .010 & .021 & .472 & .637 \\
\cline { 2 - 6 } & Parents Dependent & .020 & .034 & .578 & .563 \\
\cline { 2 - 6 } & Self-Choice Dependent & .000 & .025 & .000 & 1.000 \\
\hline
\end{tabular}

a. Not assuming the null hypothesis.

b. Using the asymptotic standard error assuming the null hypothesis.

The table above shows that parents (2\% or .020$)$ determine more influences than self-choice (0\% or .000) but too small to become significant in selecting a strand. However, the table also shows that there is no significant association between self-choice with parents influence in selection of strand in Senior High School. Therefore, self-choice with parents influence in choosing strand is not correlated with each other because the p-value $(0.563)$ is greater than the significance level (0.05).

Contrary, family factor is significant in affecting students' career choice ( $\mathrm{Su}$ et al., 2016). Parents are the one who decide what degree and school they be attending (Aguado et al., 2015). Additionally, parents have played a vital role in influencing students' career choice in selecting a strand (Hellen \& Kitainge, 2016).

Table 10. Self-choice and Peer Influence in selecting a strand

\begin{tabular}{|l|l|l|l|l|l|}
\hline $\begin{array}{l}\text { Nominal by } \\
\text { Nominal }\end{array}$ & & Value & $\begin{array}{l}\text { Asymp. Std. } \\
\text { Error }^{\mathrm{a}}\end{array}$ & Approx. T & Approx. Sig. \\
\hline Lambda & Symmetric & .022 & .015 & 1.421 & .155 \\
\cline { 2 - 6 } & Peer Dependent & .024 & .017 & 1.421 & .155 \\
\cline { 2 - 6 } & Self-Choice Dependent & .021 & .025 & .818 & .413 \\
\hline
\end{tabular}

a. Not assuming the null hypothesis.

b. Using the asymptotic standard error assuming the null hypothesis.

The table above shows that peer $(2.4 \%$ or .024$)$ determine more influence than self-choice (2.1\% or .021) but too small to become significant in selecting a strand. However, the table also shows that there is no significant association between self-choice with peer influence in selection of strand in Senior High School. Therefore, self-choice with peer influence in choosing strand is not correlated with each other because the p-value $(0.115)$ is greater than the significance level (0.05). 
Circle of peer group doesn't sway a single influence when it comes to career choice of students (Olamide \& Olawaiye, 2013). However, peer group are significant to the career choice of students (Obiyo \& Eze, 2015). Girls are more inclined with their peers influenced in selecting a strand and they dependent on them (Kazi \& Akhlaq, 2017).

\section{Summary of Findings, Conclusion, Recommendation and Limitation of The Study}

This chapter presents the summary and the majors' findings of the study. Based on these findings, the conclusion is made and recommendations were suggested.

\subsection{Findings}

The financial status of students in Jagobiao National High School is inclined to low upper class which refers to their financial status in society. Also, financial status is significantly correlated with the self-choice of students in affecting strand selection of students in Senior High of Jagobiao National High School.

The parents' influence of students in Jagobiao National High School inflect more influence than self-choice. However, it's too small to become significant in selecting a strand in senior high. Therefore, parents influence is not significant to correlate with their self-choice of student.

The peer influence of students in Jagobiao National High School inflects more influence than self-choice. In the other hand, it's too small to become significant in selecting a strand in senior high. Hence, peer Influence is not significant to correlate with their self-choice.

The self-choice of students in Jagobiao National High School inflect less influences than other influences namely parents and peer. But, mostly of the students consider their self-choice in selecting a strand. Self-choice is significantly correlated with the financial status of students in selecting a strand in senior high.

Over all, only financial status together with self-choice have shown a significant correlation and does affect students strand selection in senior high. In contrary, parents and peer influences haven't shown a significant correlation with self-choice and doesn't affect students strand selection in senior high.

\subsection{Conclusion}

Low-upper class families are prevalent in the society and it mostly influence students' self-choice in selecting their strand in senior high. Parents and peer influence are inevitable to affect students' self-choice in selecting a strand. However, it's not significant to change their decision on their selected strand. Mostly of the students in senior high level choose their strand according to what financial status and capability they have, not on their parents' and peer wants or suggested strand that they would take on senior high. All in all, senior high students are mature enough to make their own decisions but still needs to ensure and measure their financial capability and seek for guidance and support from their parents' and friends. 


\subsection{Recommendation}

The recommendation that will suggest to Jagobiao National High School was the following:

1. The school should have a financial orientation for students to widen their financial literacy their financial capability to avoid bridging in future.

2. The government should seminar and orient the head of family about financial literary for them to know on how to act in such situation that make them financial constrain.

\subsection{Limitation of the study}

Although the research paper was carefully prepared, the researcher is aware of the limitations.

The respondent of this research study is small; the researcher focused only on the senior high school students. The data that was being call do not represent the majority of the students. In addition, the researcher used an adoptive research instrument from other research paper but it was not validated.

\section{References}

Abarro, J. (2016). Factors affecting career track and strand choices of grade 9 students in the division of Antipolo and Rizal, Philippines. International Journal of Scientific and Research Publications, 6(6), 51-53. http://www.ijsrp.org/research-paper-0616/ijsrp-p5409.pdf

Abdu-Raheem, B. (2015). Parents' socio-economic status as predictor of secondary school students' academic performance in ekiti state, Nigeria. Journal of Education and Practice, 6(1), 123-128. https://files.eric.ed.gov/fulltext/EJ1083795.pdf

Aguado, C., Laguador, J., \& Deligero, J. (2015). Factors affecting the choice of school and students' level of interest towards the maritime program. Canadian Center of Science and Education, 11(21), 231-239. https://doi.org/10.5539/ass.v11n21p231

Bernardo, A., \& Resurreccion, K. F. (2018). Financial stress and well-being of Filipino students: the moderating role of external locus-of-hope. Philippine Journal of Psychology, 51(1), 33-61. https://doi.org/10.31710/pjp/0051.01.03

Bhat, M. A., Joshi, J., \& Wani, I. A. (2016). Effect of socio-economic status on academic performance of secondary school students. The International Journal of Indian Psychology, 3(4), 32-37. http://oaji.net/articles/2016/1170-1468259814.pdf

Braza, M. R., \& Guillo, R. (2015). Socio-demographic characteristics and career choice of private secondary school students. Asia Pacific Journal of Multidisciplinary Research, 3(4), 78-84. [Online] Available:

http://www.apjmr.com/wp-content/uploads/2015/11/APJMR-2015-3.4.4.12.pdf

Chevalier, A., Harmon, C., Sullivan, V., \& Walker, I. (2013). The impact of parental income and education on the schooling of their children. IZA Journal of Labor Economics, 2(8), 1-34. https://doi.org/10.1186/2193-8997-2-8 


\section{MInstitute Macho $^{\text {Mnth }}$}

Business and Economic Research ISSN 2162-4860 2020, Vol. 10, No. 1

Dahie, A. M., Mohamed, M. O., \& Moalim, A. A. (2016). Socioeconomic status and academic achievement at secondary schools in Mogadishu Somalia. International Journal in Management and Social Science, 4(1), 300-313. [Online] Available:

https://www.researchgate.net/publication/287705958_The_Impact_of_Parental_Socioeconom ic_Status_on_Students'_Academic_Achievement_in_Secondary_Schools_in_Tanzania

Daud, N., Norwani, N., \& Yusof, R. (2018). Students financial problems in higher education institutions. International Journal of Academic Research in Business and Social Sciences, 8(10), 1558-1565. https://doi.org/10.6007/IJARBSS/v8-i10/5312

Edwards, K., \& Quinter, M. (2011). Factors influencing students career choices among secondary school students in Kisumu municipality, Kenya. Journal of Emerging Trends in Educational Research and Policy Studies, 2(2), 81-87. [Online] Available:

http://www.jeteraps.scholarlinkresearch.com/articles/Factors\%20Influencing\%20Students\%2 0Career\%20Choices\%20among $\% 20$ Secondary $\% 20$ School\%20students $\% 20$ in $\% 20 \mathrm{Kisumu} \% 2$ 0Municipality, \%20Kenya.pdf

Eremie, M., \& Okwulehie, C. (2018). Factors affecting career choice among senior secondary school students in Obio/Akpor local government area of rivers state (implication to counselling). International Journal of Innovative Education Research, 6(2), 27-39. [Online] Available: http://seahipaj.org/journals-ci/june-2018/IJIER/full/IJIER-J-5-2018.pdf

Fouad, N., Kim S., Ghosh, A., Chang, W., \& Figueiredo, C. (2016). Family influence on career decision making: validation in India and the united states. Journal of Career Assessment, 24(1), 197-212. https://doi.org/10.1177/1069072714565782

Freeman, V., Lenz, J., \& Reardon, R. (2016). Career course impact on college students' career decision and affective states. Vistas Online, 1-14. [Online] Available:

https://www.counseling.org/docs/default-source/vistas/article_3289ce2bf16116603abcacff000 0bee5e7.pdf?sfvrsn=17d84b2c_4

Hellen, M., \& Kitainge, K. (2016). Influence of career preference on academic performance and graduation of male students: a case study of a university in western region of Kenya. Journal of Research in Humanities and Social Science, 4(8), 9-20. [Online] Available: http://www.questjournals.org/jrhss/papers/vol4-issue8/B480920.pdf

Holland, J. (1996). Holland's Six Personality Types. [Online] Available:

https://www.careerkey.org/choose-a-career/holland-personality-types.html\#.XdfPiugza00

Jariah, M., Husniyah, A., Laily, P., \& Britt, S. (2004). Financial behavior and problems among university students: need for financial education. Journal of Personal Finance, 3(1), 82-96. [Online] Available:

https://www.researchgate.net/publication/228404924_Financial_behavior_and_problems_am ong_university_students_Need_for_financial_education

Kaneez, B. S., \& Medha, K. (2018). Factors influencing grade 10 students' career choice in Mauritius. International Journal of Academic Research in Progressive Education and Development, 7(2), 30-44. [Online] Available: 
http://hrmars.com/hrmars_papers/Factors_Influencing_Grade_10_Students\%E2\%80\%99_Car eer_Choice_in_Mauritius.pdf

Kazi, A., \& Akhlaq, A. (2017). Factors affecting students' career choice. Journal of Research and Reflections in Education, 1(2), 187-196. [Online] Available:

https://www.researchgate.net/publication/325987918_Factors_Affecting_Students'_Career_C hoice

Kumar, S. (2016). Educational aspiration and socio-economic status among secondary school students. IOSR Journal Of Humanities And Social Science, 23(3), 25-29.

Lim, H., Heckman, S., Letkiewicz, J., \& Montalto, C. (2014). Financial stress, self-efficacy, and financial help-seeking behavior of college students. Journal of Financial Counseling and Planning, 25(2), 148-160. [Online] Available: https://files.eric.ed.gov/fulltext/EJ1048681.pdf

Mandara, J., \& Murray, C. (2000). Effects of parental marital status, income, and family functioning on African American adolescent self-esteem. Journal of Family Psychology, 14(3), 475-490. https://doi.org/10.1037/0893-3200.14.3.475

Nyamwange, J. (2016). Influence of student's interest on career choice among first year university students in public and private universities in Kisi County, Kenya. Journal of Education and Practice, 7(4), 96-107. [Online] Available: https://eric.ed.gov/?id=EJ1092415

Obiyo, N., \& Eze, C. (2015). Parental socio-economic-status as predictor of vocational aspirations of secondary school students in Nigeria: Implications for peace, curriculum planners and special educators. International Journal of Curriculum and Instruction, 7(2), 18-34. [Online] Available:

https://www.semanticscholar.org/paper/Parental-socio-economic-status-as-predictor-of-of-Ob iyo-Eze/37c0e7001a444bb31bbf895b64c3254fe8da600d

Obiunu, J., \& Ebunu, O. (2010). Factors affecting career development of senior secondary school students in Ethiope east local government area, Delta state, Nigeria. International Research Journals, 1(11), 594-599. [Online] Available:

https://www.researchgate.net/publication/228498261_Factors_affecting_career_development _of_senior_secondary_school_students_in_Ethiope_east_local_government_area_Delta_state _Nigeria

Ogunshola, F., \& Adewale, A. M. (2012). The effects of parental socio-economic status on academic performance of students in selected schools in Edu Lga of Kwara State Nigeria. International Journal of Academic Research in Business and Social Sciences, 2(7), 230-239. [Online] Available:

https://www.researchgate.net/publication/268060873_The_Effects_of_Parental_Socio-Econo mic_Status_on_Academic_Performance_of_Students_in_Selected_Schools_in_Edu_Lga_of_ Kwara_State_Nigeria

Olamide, S., \& Olawaiye, (2013). The factors determining the choice of career among secondary school students. The International Journal Of Engineering And Science, 2(6), 33-44. [Online] Available: http://theijes.com/papers/v2-i6/Part.2/E0262033044.pdf 


\section{Macrothink}

Business and Economic Research ISSN 2162-4860 2020, Vol. 10, No. 1

Pascual, N. (2014). Factors affecting high school students' career preference: a basis for career planning program. International Journal of Sciences: Basic and Applied Research, 16(1), 1-14. [Online] Available:

http://www.urs.edu.ph/wp-content/uploads/2016/06/2261-4881-1-PB.pdf

Saifi, S., \& Mehmood, T. (2011). Effects of socioeconomic status on students achievement. International Journal of Social Sciences and Education, 1(2), 119-128. [Online] Available: https://www.ijsse.com/sites/default/files/issues/2011/v1i2/p3/Paper.pdf

Sollano, A., Duhaylongsod, K. A., Aviso, M., \& Moneva, J. (2018). Daily allowance and academic performance. International Journal of Engineering Science and Computing, 8(6), 19685-19690. [Online] Available:

http://ijesc.org/upload/28b2c394d0607c05f073109e6edf84dd.Daily\%20Allowance\%20and\% 20Academic\%20Performance.pdf

Su, M., Chang, T., Wu, C., \& Liao, C. (2016). Factors affecting the student career decision-making of junior high school students in Central Taiwan Area. International Journal of Information and Education Technology, 6(11), 843-850.

https://doi.org/10.7763/IJIET.2016.V6.803

Tran, A., Lam, C., \& Legg E, (2018). Financial stress, social supports, gender, and anxiety during college: a stress-buffering perspective. The Counseling Psychologist, 46(7), 846-869. https://doi.org/10.1177/0011000018806687

\section{Glossary}

Financial status is referring to a standing of the family which was based on money in society.

Disproportionate is referring to an irregularly a large amount of money that control by certain people or group of people.

Strand specialization is referring to a chosen strand that aim by a student to be their profession soon.

Family financial income is referring to a money that accustomed by family to support their needs that gain from work.

\section{Appendix}

Part I. Financial Status

What is your family monthly income?
a.) $1.000-12,500$
b.) $12,501-25,000$
c.) $25,001-37,500$
d.) $37,501-50,000$

Part II. Factors

Kindly put a $(\sqrt{ })$ and rate yourself honestly using the following scales: 


\section{Macrothink}

1=Strongly Disagree, 2=Disagree, 3=Agree, 4=Strongly Agree

\begin{tabular}{|c|c|c|c|c|}
\hline A. Parents Factors & 1 & 2 & 3 & 4 \\
\hline 1. I seek my parents' advice in choosing strand. & & & & \\
\hline 2. I choose this strand based on my parents' occupation. & & & & \\
\hline 3. My parents recommend me to take this strand. & & & & \\
\hline 4. I choose this strand based on my parents' perception of my future career. & & & & \\
\hline 5. I choose this strand based on my parents' moral support. & & & & \\
\hline B. Peer Factors & & & & \\
\hline 1. I consult my friends before choosing a strand. & & & & \\
\hline 2. I go by the trend in class/campus in choosing the strand. & & & & \\
\hline 3. My peer group recommend me to take this strand. & & & & \\
\hline 4. I and my peer group share thoughts and opinion in choosing strand. & & & & \\
\hline 5. My friends will acknowledge me if I choose the strand same with them. & & & & \\
\hline C. Self-choice Factors & & & & \\
\hline 1. I based my chosen strand on the basis of my skills and abilities. & & & & \\
\hline 2. I choose this strand based on my dream career. & & & & \\
\hline $\begin{array}{l}\text { 3. I choose this strand based on the satisfaction that I will get soon } \\
\text { from my future job. }\end{array}$ & & & & \\
\hline 4. I choose this strand based on my interest. & & & & \\
\hline 5. I choose this strand because I'm good at doing at it. & & & & \\
\hline
\end{tabular}

\section{Copyright Disclaimer}

Copyright for this article is retained by the author(s), with first publication rights granted to the journal.

This is an open-access article distributed under the terms and conditions of the Creative Commons Attribution license (http://creativecommons.org/licenses/by/4.0/). 